\title{
HTLV-1 proviral load levels in adult T-cell leukemia/lymphoma (ATL) in Bahia, Brazil
}

\author{
Isabela Archanjo ${ }^{1}$, Marcelo Magalhães ${ }^{1}$, Everton S Batista ${ }^{1}$, Kiyoshi Fukutani $^{2}$, Achilea Bittencourt ${ }^{3}$, Lourdes Farre ${ }^{1 *}$ \\ From 15th International Conference on Human Retroviruses: HTLV and Related Viruses \\ Leuven and Gembloux, Belgium. 5-8 June 2011
}

In human T-cell leukemia virus type 1 (HTLV-1) infection, high levels of proviral load (PVL) have been associated with the development of HTLV-1-associated myelopathy/tropical spastic paraparesis(HAM/TSP) and infective dermatitis associated with HTLV-1 (IDH). Few data are available on PVL in the different clinical types of adult T-cell leukemia/lymphoma (ATL), a malignancy associated with HTLV-1. PVL assessment may constitute a useful tool for classifying types of ATL. The objective of this study was to assess the PVL levels of patients with different clinical types of ATL. The study included 39 samples from patients with the following clinical subtypes of ATL: acute $(\mathrm{n}=11)$, chronic $(\mathrm{n}=11)$, smoldering $(\mathrm{n}=$ $10)$, lymphoma $(\mathrm{n}=5)$ and primary cutaneous tumoral ( $\mathrm{n}$ =2). PVL was quantified using quantitative real-time PCR, taking the tax region of provirus into consideration and using $\beta$-globulin as the reference gene. PVL levels were highest in the chronic and acute subtypes, but there was no statistically significant difference between these two subtypes ( $p=0.6936$ ). In smoldering ATL, PVL levels were lower compared to the levels found in the acute $(\mathrm{p}=$ $0.0124)$ and chronic $(p=0.0067)$ subtypes. In the primary cutaneous tumoral and lymphoma subtypes, PVL levels were intermediate but there were no statistically significant differences between these and the other clinical subtypes. The present results suggest that PVL levels in ATL are related to the lymphocytosis observed in the acute and chronic subtypes, but appear to be unrelated to the aggressiveness of the disease.

\section{Author details}

'Laboratory of Experimental Pathology, CPQGM, FIOCRUZ, Salvador, Bahia, 40296710, Brazil. ${ }^{2}$ Laboratory of Immunoparasitology, CPQGM, FIOCRUZ,

\footnotetext{
* Correspondence: Lfarre@bahia.fiocruz.br

'Laboratory of Experimental Pathology, CPQGM, FIOCRUZ, Salvador, Bahia, 40296710, Brazil

Full list of author information is available at the end of the article
}

Salvador, Bahia, 40296710, Brazil. ${ }^{3}$ Department of Pathology, HUPES, Federal University of Bahia, Salvador, Bahia, 40296710, Brazil.

Published: 6 June 2011

doi:10.1186/1742-4690-8-S1-A91

Cite this article as: Archanjo et al:: HTLV-1 proviral load levels in adult Tcell leukemia/lymphoma (ATL) in Bahia, Brazil. Retrovirology 2011 8(Suppl 1):A91.
Submit your next manuscript to BioMed Central and take full advantage of:

- Convenient online submission

- Thorough peer review

- No space constraints or color figure charges

- Immediate publication on acceptance

- Inclusion in PubMed, CAS, Scopus and Google Scholar

- Research which is freely available for redistribution

Submit your manuscript at www.biomedcentral.com/submit

\section{() Biomed Central}

C Biomed Central

C 2011 Archanjo et al; licensee BioMed Central Ltd. This is an open access article distributed under the terms of the Creative Commons Attribution License (http://creativecommons.org/licenses/by/2.0), which permits unrestricted use, distribution, and reproduction in any medium, provided the original work is properly cited. 